Ralina, et al/Jurnal Ekonomi Syariah Teori dan Terapan Vol. 6 No. 9 September 2019: 1795-1803;

PENGARUH KINERJA KEUANGAN DAN KINERJA LINGKUNGAN TERHADAP NILAI PERUSAHAAN

PERTAMBANGAN DI ISSI PERIODE 2013-2017

\title{
PENGARUH KINERJA KEUANGAN DAN KINERJA LINGKUNGAN TERHADAP NILAI PERUSAHAAN PERTAMBANGAN DI ISSI PERIODE 2013-20171
}

\author{
Lidia Ralina \\ Departemen Ekonomi Syariah - Fakultas Ekonomi dan Bisnis - Universitas Airlangga \\ Email: lidia.ralina-2014@feb.unair.ac.id \\ Ari Prasetyo \\ Departemen Ekonomi Syariah - Fakultas Ekonomi dan Bisnis - Universitas Airlangga \\ Email: ari.prasetyo@f@feb.unair.ac.id
}

ABSTRACT:

This study analyzed the influence of Islamic Social Reporting (ISR), Return on Asset, and Current Ratio on the value of the companies which were registered in ISSI in 2013-2017. This research used panel data regression analysis to combine time series data and cross section data. The results of the research with estimation model of Random Effect showed that ISR, ROA and CR partially had significant effects on the value of the company. ISR, ROA and CR silmutanously affect on the value of the mining companies registered in ISSI 20132017.

Keywords: Islamic Social Reporting, Return on Asset, Current Ratio, and Firm Value.

I. PENDAHULUAN

Investor mempertimbangkan

banyak faktor dalam berinvestasi. Prospek

perusahaan akan datang dapat tercermin dari nilai perusahaan. Perusahaan akan memperkerjakan para ahli dalam bidangnya seperti manajer dan komisaris untuk mengelola perusahaan agar perusahaan dapat memacu kinerja perusahaan yang bertujuan meningkatkan nilai perusahaan sehingga terjadi peningkatan permintaan saham yang dapat meningkatkan nilai perusahaan tersebut. Nilai perusahaan tidak hanya ditentukan oleh faktor kevangan suatu perusahaan melainkan terdapat pula faktor non keuangan perusahaan. Perusahaan yang memperhatikan keduanya, dipercaya mempunyai nilai perusahaan yang lebih tinggi dibanding yang perusahaan yang hanya memperhatikan satu sisi saja, hal ini dapat meningkatkan nilai perusahaan.

Silverman (1993, dalam Listiana, 2015) berpendapat bahwa laporan tahunan merupakan sumber informasi penting yang diproduksi secara sistematis, dapat diakses secara luas dan mengkomunikasikan secara detail mengenai kegiatan operasi perusahaan. Perusahaan yang mengungkapan aktivitas sosial dan lingkungan dalam laporan tahunannya secara detail akan mempunyai nilai tambah bagi para pemegang saham dan pemangku kepentingan. Pengungkapan dalam laporan tahunan terdiri dari pengungkapan wajib (mandatory disclosure) dan pengungkapan sukarela (voluntary disclosure). Pengungkapan wajib terdiri dari informasi yang minimal harus ditampilkan berdasarkan peraturan

\footnotetext{
1 Jurnal ini merupakan bagian dari Skripsi yang ditulis oleh Lidia Ralina, NIM:041411431150, yang diuji pada tanggal 19 Juli 2018.
} 
Ralina, et al/Jurnal Ekonomi Syariah Teori dan Terapan Vol. 6 No. 9 September 2019: 1795-1803; PENGARUH KINERJA KEUANGAN DAN KINERJA LINGKUNGAN TERHADAP NILAI PERUSAHAAN PERTAMBANGAN DI ISSI PERIODE 2013-2017

oleh regulator Badan Pengawas Pasar Modal Lembaga Keuangan (BAPEPAM-LK) dan sesuai dengan Pernyataan Standar Akuntansi Keuangan (PSAK).

Dalam laporan tahunan terdapat kinerja keuangan yang dapat menjadi faktor dalam peningkatan nilai perusahaan. Di antaranya yaitu rasio profitabilitas (ROA) dan rasio likuiditas (CR) perusahaan.

Menurut Sujoko dan Subiantoro (2007) dengan tingginya profitabilitas, investor maupun calon investor akan memandangan bahwa perusahaan memiliki prospek yang baik sehingga merespon positif sinyal tersebut dan nilai perusahaan akan meningkat. CR merupakan rasio yang biasa digunakan untuk mengukur kemampuan aktiva lancar dalam menutupi hutang lancar yang dimiliki oleh perusahaan. Apabila nilai CR rendah maka akan menunjukkan likuditas perusahaan yang buruk, sebaliknya apabila nilai CR tinggi akan menjukkan likuiditas perusahaan baik (Sudana, 2011:21).

Selain laporan keuangan, manajemen mengungkapkan laporan sukarela yang terdapat dalam laporan tahunan dengan harapan meningkatkan nilai perusahaan yang tercermin dalam harga saham. Perusahaan terdaftar di Indeks Saham Syariah Indonesia (ISSI) sebagaimana perusahaan lainnya tidak luput dari kewajiban CSR.

Maulida (2014) menyatakan bahwa pengukuran CSR mengacu pada
Global Reporting Indexs (GRI), namun pengukuran tersebut masih kurang tepat diterapkan karna tidak sesuai dengan kaidah Islam dikarenakan indeks tersebut belum bisa menggambarkan prinsip Islam yang terbebas dari unsur gharar, riba, serta transaksi-transaksi yang diharamkan oleh Islam.

ISR yang mengacu kepada Islamic Social Reporting Indexs (ISRI) yang pertama kali diusulkan oleh Haniffa. Menurut Haniffa, terdapat keterbatasan dalam laporan sosial konvensional sehingga ia mengemukakan kerangka konseptual ISR tidak hanya membantu para pengambilan keputusan tetapi juga untuk perusahaan dalam rangka pemenuhan kewajiban terhadap Allah SWT dan masyarakat sekitar. (Haniffa, 2002).

Kemudian dikembangkan standar pelaporan yang berkaitan dengan tanggung jawab sosial ekonomi pada lembaga-lembaga keuangan syariah oleh Accounting and Auditing Ogarnization for Islamic Financial Institutions (AAOIFI) sebagai lembaga non-profit internasional independen yang berusaha menyiapkan standar akuntansi, standar auditing, tata kelola perusahaan, kode etik, dan standar syariah bagi perbankan dan lembagalembaga keuangan syariah lainnya.

Negara Indonesia sangat diuntungkan dari sisi geografisnya karena terdapat struktur kepulauan yang banyak sekali mengandung sumber daya alam salah satunya berupa hasil tambang. 
Ralina, et al/Jurnal Ekonomi Syariah Teori dan Terapan Vol. 6 No. 9 September 2019: 1795-1803; PENGARUH KINERJA KEUANGAN DAN KINERJA LINGKUNGAN TERHADAP NILAI PERUSAHAAN PERTAMBANGAN DI ISSI PERIODE 2013-2017

Ketergantungan akan pemakaian sumber daya alam dapat berujung dengan eksploitasi berlebihan dan tidak mempertimbangkan daya dukung lingkungan akan berdampak pada kehancuran bumi. Adanya permasalahan lingkungan maupun sosial yang ditimbulkan oleh perusahaan, pemerintah mengeluarkan Undang-Undang RI No. 40 Tahun 2007 tentang Perseroan Terbatas mengenai adanya kewajiban perusahaan khususnya dalam melaksakan eksplorasi sumber daya alam untuk melaksanakan CSR.

Berdasarkan latar belakang tersebut, maka judul penelitian ini adalah "Pengaruh Kinerja Keuangan dan Kinerja Lingkungan Terhadap Nilai Perusahaan Pertambangan di ISSI Periode 2013-2017".

Adapun rumusan masalah yang diambil adalah sebagai berikut:

1. Apakah pengungkapan Islamic Social Reporting (ISR) berpengaruh secara parsial terhadap nilai perusahaan pada perusahaan pertambangan yang terdaftar di ISSI tahun 2013-2017?

2. Apakah Return on Asset berpengaruh secara parsial terhadap nilai perusahaan pada perusahaan pertambangan yang terdaftar di ISSI tahun 2013-2017?

3. Apakah Current Ratio berpengaruh secara parsial terhadap nilai perusahaan pada perusahaan pertambangan yang terdaftar di ISSI tahun 2013-2017?
4. Apakah pengungkapan Islamic Social Reporting (ISR), Return on Asset (ROA), dan Current Ratio (CR) berpengaruh secara simultan terhadap nilai perusahaan pada perusahaan pertambangan yang terdaftar di ISSI tahun 2013-2017?

\section{LANDASAN TEORI}

Nilai perusahaan sangat penting diperhatikan bagi perusahaan karena dengan memaksimalkan nilai perusahaan maka akan memaksimalkan kemakmuran pemegang saham dan meningkatkan kepercayaan pasar akan prospek kinerja perusahaan pada saat ini maupun akan datang.

Sesuai dengan stakeholder theory, bahwa stakeholder Muslim sebagai pengambil keputusan mengharapkan perusahaan mengungkapan tanggung jawab sosial berbasis syariah sehingga membuktikan bahwa operasional perusahaan dijalankan sesuai hukum Islam sebagai tindak lanjut dari perusahaan dalam penerapan yang efektif melalui implementasi bisnis yang transparan dan dapat dipertanggungjawabkan. AlQur'an surah Al-Ar'aaf (7) ayat 85 menekankan kepada manusia untuk menjaga kehidupan sosial dan lingkungan seperti tertera dalam sebagai berikut:

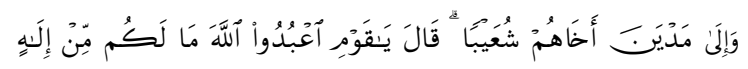

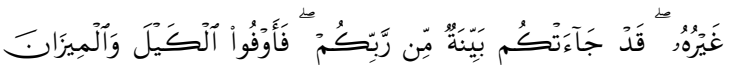

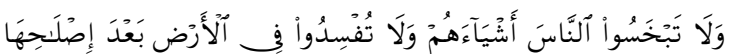

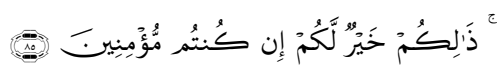


Ralina, et al/Jurnal Ekonomi Syariah Teori dan Terapan Vol. 6 No. 9 September 2019: 1795-1803; PENGARUH KINERJA KEUANGAN DAN KINERJA LINGKUNGAN TERHADAP NILAI PERUSAHAAN PERTAMBANGAN DI ISSI PERIODE 2013-2017

Wailā madyana akhahum syu'aiba(n), qāla yā qawmi'i-budū'l-Lāha mā lakum min ilāhin gairuh(u), qad jā'atkum bayyinatun min rabbikum, faawfū'l-kaila wa'l-mizāna walā tabkhasū'n-nāsa asyyā 'ahum walā tufsidū fi'l-ar i ba'da i lā ihā, żālikum khairun lakum in kuntum mu'minin(a).

Artinya: "... Sempurnakanlah takaran dan timbangan, dan janganlah kamu merugikan orang sedikit pun. Janganlah kamu berbuat kerusakan di Bumi setelah (diciptakan) dengan baik" (QS 7:85, Departemen Agama RI)

\section{Hubungan Islamic Social Reporting terhadap Nilai Perusahaan}

Informasi dalam laporan keuangan maupun laporan tahunan memiliki peran penting bagi perusahaan dalam mencerminkan nilai perusahaan bagi investor untuk menilai baik atau buruknya nilai suatu perusahaan dalam mengambil keputusan saat berinvestasi. Investor tidak hanya melihat dari segi laba perusahaan tetapi pelaporan tanggung jawab sosial perusahaan juga menjadi pertimbangan dalam pengambilan keputusan. Pelaporan CSR Islami dalam laporan tahunan perusahaan berpengaruh signifikan positif terhadap nilai perusahaan apabila dilakukan secara berkelanjutan oleh perusahaan karena dapat menarik minat investor untuk berinvestasi dan dapat meningkatkan nilai perusahaan karena dengan semakin tinggi nilai perusahaan akan diikuti oleh tingginya kemakmuran stakeholder. Sehingga pengungkapan Islamic Social Reporting (ISR) berpengaruh terhadap nilai perusahaan (Arshad et al, 2012; Ratri, 2016).

\section{Hubungan Return on Asset terhadap Nilai Perusahaan}

Salah satu rasio profitabilitas yakni ROA. Kemampuan perusahaan menghasilkan perusahaan dan efisiensi operasional perusahaan dalam menggunakan harta yang dimiliki dapat diukur dengan profitabilitas (Dhani. 2016).

Ulupui (2007) menyatakan semakin efisien perputaran aset atau semakin tinggi profit margin yang diperoleh perusahaan akan berdampak pada peningkatan nilai perusahaan. Serupa dengan penelitian lain yang menyatakan bahwa profitabilitas (ROA) berpengaruh positif secara signifikan terhadap nilai perusahann yang diukur dengan Tobin's $Q$ (Gamayumi, 2013).

Hal ini menujukkan bahwa dengan tingginya profitabilitas dapat mempengaruhi investor meningkatkan permintaan saham. Peningkatan permintaan saham akan menaikkan nilai perusahaan. Sehingga Return on Asset (ROA) berpengaruh terhadap nilai perusahaan.

\section{Hubungan Current Ratio terhadap Nilai Perusahaan}

Rasio CR dihitung dengan membagi aktiva lancar dengan kewajiban jangka pendeknya. Semakin tinggi ratio dihasilkan menujukkan semakin likuid perusahaan dalam mengelola 
Ralina, et al/Jurnal Ekonomi Syariah Teori dan Terapan Vol. 6 No. 9 September 2019: 1795-1803; PENGARUH KINERJA KEUANGAN DAN KINERJA LINGKUNGAN TERHADAP NILAI PERUSAHAAN PERTAMBANGAN DI ISSI PERIODE 2013-2017

aktiva lancar untuk membayar kewajibannya, sebaliknya semakin rendah rasio dihasilkan maka menujukkan pengelolaan aktiva lancar dan hutang lancar tidak begitu likuid.

Putra (2014) menyatakan bahwa CR memberikan gambaran kemampuan perusahaan dalam memenuhi kewajibankewajiban jangka pendek. Prosentase CR yang tinggi memiliki arti bahwa perusahaan memiliki likuiditas yang baik sehingga investor memberikan persepsi positif terhadap perusahaan karena perusahaan memiliki aset lainnya yang dapat dicairkan sewaktu-waktu sehingga meningkatkan nilai perusahaan. Sehingga Return on Asset (ROA) berpengaruh terhadap nilai perusahaan.

\section{METODE PENELITIAN}

Pendekatan yang digunakan dalam penelitian ini adalah pendekatan kuantitatif. Adapun variabel yang digunakan dalam penelitian ini terdiri dari 4 variabel yaitu, ISR, ROA dan CR sebagai variabel independen dan nilai perusahaan sebagai variabel dependen. Populasi dalam penelitian ini adalah perusahaan pertambangan di Indonesia yang terdaftar di ISSI dan memiliki laporan tahunan lengkap periode 2013 hinga 2017. Dengan sampel sebanyak 16 perusahaan pertambangan yang terdaftar di ISSI.

\section{Definisi Operasional}

$$
\text { Islamic Social reporting }
$$

menggambarkan seberapa luas pengungkapan pertanggungjawaban yang telah dilakukan perusahaan berdasarkan AAOIFI dengan 6 (enam) prinsip syariah dalam 33 item yang akan dichecklist. Rumus yang digunakan untuk menghitung ISR adalah sebagai berikut:

$\frac{\text { Total Skor pada Perusahaan }}{\text { Total Skor Maksimum }}$.

Return on Asset (ROA) digunakan karena mampu mengukur kemampuan perusahaan mengelola dana yang diinvestasikan dalam keseluruhan aktiva yang menghasilkan keuntungan. Rumusnya adalah:

Laba Bersih Setelah Pajak

Current Ratio (CR) digunakan karena mampu mengukur kemampuan perusahaan untuk membayar utang lancar dengan menggunakan aktiva yang tersedia. CR memiliki rumus sebagai berikut :

Aktiva Lancar

Nilai perusahaan akan diukur

menggunakan rasio Tobin's $Q$

dikarenakan pada rasio ini perusahaan tidak hanya terfokus pada investor dalam bentuk saham saja karena memasukkan ekuitas perusahaan dan juga seluruh aset perusahaan

Tobin's $Q=\left[\frac{(O S x P)+(D+I)-C A}{T A}\right]$

Keterangan :

Tobin's $Q=$ nilai perusahaan, $O S=$ Oustanding Shares, $\mathrm{P}=$ Stock Prices, $\mathrm{D}=$ Total Debt of Company, I = Total Inventory, $\mathrm{CA}=$ Current Assets, $\mathrm{TA}=$ Total Assets

\section{Teknik Analisis}

Teknik analisis yang digunakan dalam penelitian ini adalah regresi panel. 
Ralina, et al/Jurnal Ekonomi Syariah Teori dan Terapan Vol. 6 No. 9 September 2019: 1795-1803; PENGARUH KINERJA KEUANGAN DAN KINERJA LINGKUNGAN TERHADAP NILAI PERUSAHAAN PERTAMBANGAN DI ISSI PERIODE 2013-2017

Regresi panel adalah kombinasi dari data time series dan cross section. Data time series merupakan data yang disusun berdasarkan urutan waktu, Sedangkan cross section merupakan data yang dikumpulkan pada waktu yang sama dari beberapa daerah (Gujarati, 2013:235)

Terdapat tiga metode estimasi yang bisa digunakan dalam metode regresi data panel, yakni:

1) Pooled Least Square (PLS),

2) Fixed Effect Model (FEM), dan

3) Random Effect Model (REM)

Pada penelitian ini menggunakan model estimasi regresi data panel dengan dua langkah pengujian. Pertama, Uji F (Uji Chow) digunakan untuk menentukan antara model Pooled Least Square (PLS) dengan Fixed Effect Model (FEM), dan yang kedua uji Hausman digunakan untuk menentukan antara Fixed Effect Model (FEM) dengan Random Effect Model (REM).

\section{HASIL PENELITIAN DAN PEMBAHASAN}

Deskriptif variabel penelitian ini dijelaskan dengan data penelitian perusahaan pertambangan yang terdaftar di ISSI tahun 2013-2017 dan memiliki data yang lengkap. Analisis deskriptif pada penelitian ini bertujuan untuk menguraikan gambaran mengenai variabel-variabel penelitian. Deskripsi tersebut meliputi mean, standar devasi, nilai minimum dan maksimum.

\section{Tabel 1}

\section{Statistik Deskriptif}

\begin{tabular}{|c|c|c|c|c|}
\hline & Mean & Std. D & Min & Maks \\
\hline $\mathrm{X}_{1}$ & 0.576 & 0.127 & 0.212 & 0.848 \\
\hline $\mathrm{X}_{2}$ & 5.132 & 11.95 & -72.13 & 39 \\
\hline $\mathrm{X}_{3}$ & 2.336 & 1.355 & 0.493 & 8.142 \\
\hline $\mathrm{X}_{4}$ & 1.193 & 1.405 & -0.147 & 11.88 \\
\hline
\end{tabular}

Uji Chow

Uji chow digunakan untuk memilih antara model Pooled Least Square (PLS) atau Fixed Effect Model (FEM) yang sebaiknya dipakai. Berikut hipotesis Uji Chow:

Ho : Pooled Least Square (PLS)

$\mathrm{H}_{1} \quad$ : Fixed Effect Model (FEM)

Berdasarkan hasil pengujian yang tertera pada table uji chow diperoleh probabilitas cross-section F sebesar 0,0000. \%) sehingga $\mathrm{H}_{0}$ ditolak dan $\mathrm{H}_{1}$ diterima yang menyatakan Fixed Effect model merupakan model yang tepat dibandingkan dengan Pooled Least square (PLS).

\section{Uji Hausman}

Uji chow digunakan untuk memilih antara model tepat antara Fixed Effect Model (FEM) dan Random Effect Model (REM) yang sebaiknya dipakai. Berikut hipotesis Uji Chow:

$$
\begin{array}{ll}
\mathrm{H}_{0} & \text { : Model random effect (REM) } \\
\mathrm{H}_{1} & \text { : Model fixed effect (FEM) }
\end{array}
$$

Berdasarkan hasil pengujian yang tertera pada table uji chow diperoleh probabilitas cross-section F sebesar 0,3877. sehingga $\mathrm{HI}$ ditolak dan $\mathrm{HO}$ diterima yang menyatakan Random Effect Model 
Ralina, et al/Jurnal Ekonomi Syariah Teori dan Terapan Vol. 6 No. 9 September 2019: 1795-1803; PENGARUH KINERJA KEUANGAN DAN KINERJA LINGKUNGAN TERHADAP NILAI PERUSAHAAN PERTAMBANGAN DI ISSI PERIODE 2013-2017

merupakan model yang tepat dibandingkan dengan Fixed Effect Model

Tabel 2

Hasil Random Effect Model

\begin{tabular}{|l|l|l|}
\hline & Coef. & $P>|\dagger|$ \\
\hline ROA & .543621 & 0.018 \\
\hline CR & .1249197 & 0.008 \\
\hline ISR & 1.272256 & 0.026 \\
\hline
\end{tabular}

Uji Hipotesis

Uji F

Pengujian ini digunakan untuk menilai pengaruh variabel independen terhadap variabel dependen secara serentak atau bersama. Berdasarkan hasil di atas hasil regresi data panel menggunakan estimasi Random Effect Model didapatkan probabilitas F-statistik sebesar 0,0000 yang lebih kecil dari tingkat signifikansi lima persen, maka variabel independen (Islamic Social Reporting, Return on Asset dan Current Ratio) berpengaruh secara bersama-sama (simultan) terhadap variabel dependen yakni nilai perusahaan Uji T

Pengujian ini digunakan untuk menilai pengaruh masing-masing variabel independen terhadap variabel dependen. Berdasarkan hasil di atas hasil regresi data panel menggunakan estimasi Random Effect Model, berikut adalah penjabaran hasil masing-masing uji-t:

Variabel Return On Assets (ROA)

Keputusan : Tolak $\mathrm{H}_{0}$ karena nilai $\mathrm{p}$ value $>0,05$ $: 0,018>0,05$

Kesimpulan : Ada pengaruh antara variabel return on assets terhadap Tobins'Q tahun 2013-2017.

Variabel Current Ratio (CR)

Keputusan : Tolak Ho karena nilai pvalue $>0,05$

$: 0,008>0,05$

Kesimpulan : Ada pengaruh antara variabel current ratio terhadap Tobins'Q tahun 2013-2017.

Variabel Islamic Social Reporting (ISR)

Keputusan : Tolak $\mathrm{H}_{0}$ karena nilai $\mathrm{p}$ value $>0,05$

$: 0,026<0,05$

Kesimpulan : Ada pengaruh antara variabel Islamic Social Reporting terhadap Tobins' $Q$ tahun 2013-2017.

\section{Koefisien determinasi $\left(\mathbf{R}^{2}\right)$}

Pada pengujian ini bertujuan untuk mengukur sejauh mana kemampuan model dalam menerangkan variasi variabel bebasnya. Hasil determinasi didapat adalah nilai $R$ Square menyatakan bahwa sebanyak 0,5148 atau 51,48\% variabel dependennya yaitu Tobins' $Q$ dapat dijelaskan oleh variabel independen pada penelitian ini.

\section{HASIL DAN PEMBAHASAN}

\section{Islamic Social Reporting Berpengaruh terhadap Nilai Perusahaan}

Berdasarkan hasil olah data statistik penelitian diperoleh bahwa Islamic Social Reporting (ISR) secara parsial berpengaruh terhadap nilai perusahaan yang dapat dilihat dari hasil uji t. Hal ini menunjukkan bahwa besar kecilnya 
Ralina, et al/Jurnal Ekonomi Syariah Teori dan Terapan Vol. 6 No. 9 September 2019: 1795-1803; PENGARUH KINERJA KEUANGAN DAN KINERJA LINGKUNGAN TERHADAP NILAI PERUSAHAAN PERTAMBANGAN DI ISSI PERIODE 2013-2017

pengungkapan ISR akan mempengaruhi nilai perusahaan. Nilai koefisien hasil uji $\dagger$ variabel Islamic Social Reporting sebesar 1,27226. Ini berarti bahwa setiap kenaikan ISR sebesar 1 satuan akan menurunkan rasio Tobins' $Q$ sebesar 1,27226 satuan.

$\begin{array}{cll}\text { Sejalan } & \text { dengan } & \text { penelitian } \\ \text { sebelumnya } & \text { bahwa } & \text { dengan } \\ \text { mengungkapan } & \text { ISR pada } & \text { laporan }\end{array}$
tahunan akan meningkatkan nilai perusahaan, baik bagi investor secara individual maupun secara keseluruhan. Nilai perusahaan yang baik dapat menarik perhatian investor, meningkatkan investasi, menunjukkan kinerja perusahaan yang baik, mendapatkan reputasi positif serta mendapatkan komentar baik dari analis keuangan. Hal ini mengidentifikasikan pengungkapan ISR dapat digunakan manajer untuk mempengaruhi persepsi para stakeholder muslim untuk menentukan pilihannya secara syariah. (Arshad et al, 2012)

Return on Asset Berpengaruh terhadap Nilai Perusahaan

Berdasarkan hasil olah data statistik penelitian diperoleh bahwa Return on Asset (ROA) secara parsial berpengaruh signifikan dari hasil uji t. Hal ini menunjukkan bahwa besar kecilnya ROA mempengaruhi nilai perusahaan. Nilai koefisien hasil uji $t$ variabel ROA sebesar 0,05436 dan dengan nilai probabilitas 0.018 menunjukkan ROA tidak berpengaruh terhadap nilai perusahaan, hal ini berarti setiap kenaikan ROA sebesar
$1 \%$ akan menaikkan nilai perusahaan sebesar $0,05436 \%$.

Hasil penelitian ini mendukung penelitian sebelumnya yang menyatakan bahwa kinerja kevangan (ROA) berpengaruh positif dan signifikan terhadap nilai perusahaan yang diukur dengan Tobin's Q. Laporan keuangan yang ditunjukkan dengan kinerja keuangan (ROA) ternyata masih digunakan oleh para investor untuk memprediksi nilai suatu perusahaan (Ratri, 2016)

Current Asset Berpengaruh terhadap Nilai Perusahaan

Berdasarkan hasil olah data statistik penelitian diperoleh bahwa Current Ratio (CR) secara parsial berpengaruh terhadap nilai perusahaan yang dapat dilihat dari hasil uji t. Hal ini menunjukkan bahwa besar kecilnya CR mempengaruhi nilai perusahaan. Dalam tabel 4.9, nilai koefisien hasil uji $\dagger$ variabel CR sebesar 0.8097383 dan dengan nilai probabilitas 0.008 menunjukkan CR berpengaruh terhadap nilai perusahaan, hal ini berarti setiap kenaikan CR sebesar 1\% akan menaikkan nilai perusahaan sebesar 0.8097383 satuan.

Hasil penelitian ini sejalan dengan penelitian sebelumnya yang mendukung penelitian lain mengenai pengaruh $C R$ terhadap nilai perusahaan yang dilakukan oleh Putra (2014). Kontribusi CR dalam meningkatkan nilai perusahaan dikarenakan perusahaan mampu memenuhi kewajiban jangka pendeknya, 
Ralina, et al/Jurnal Ekonomi Syariah Teori dan Terapan Vol. 6 No. 9 September 2019: 1795-1803; PENGARUH KINERJA KEUANGAN DAN KINERJA LINGKUNGAN TERHADAP NILAI PERUSAHAAN PERTAMBANGAN DI ISSI PERIODE 2013-2017

di mana semakin besar prosentase CR maka perusahaan akan memiliki nilai perusahaan yang baik, sehingga hal ini memberikan persepsi positif kepada investor terhadap kondisi perusahaan yang dapat meningkatkan nilai perusahaan (Kusuma, 2015).

\section{SIMPULAN}

Hasil penelitian menunjukkan bahwa ISR dan CR secara parsial berpengaruh signifikan terhadap nilai perusahaan dan ROA secara parsial tidak berpengaruh signifikan terhadap nilai perusahaan. Pada penelitian ini juga dapat menunjukkan ISR, ROA dan CR berpengaruh secara simultan terhadap nilai perusahaan.

\section{DAFTAR PUSTAKA}

Arshad, R., Othman, S., \& Othman, R. 2012. Islamic Corporate Social Responsibility, Corporate Reputation and Performance. World Academy of Science, Engineering And Technology (64), 1070-1074.

Anzlina, Corry Winda dan Rustam. 2013. "Pengaruh Tingkat Likuiditas, Solvabilitas, Aktivitas, dan Profitabilitas Terhadap Nilai Perusahaan pada Perusahaan Real Estate dan Property di BEI Tahun 2006-2008". Jurnal Ekonomi, Vol. 16, No. 2, April 2013.

Dhani, Isabella Permata. Pengaruh Pertumbuhan Perusahaan, Struktur Modal dan Profitabilitas Terhadap Nilai Perusahaan Manufaktur Yang
Terdaftar di Bursa Efek Indonesia Tahun 2013-2015. Skripsi tidak diterbitkan. Surabaya: Universitas Airlangga

Gujarati. 2013. Dasar dasar Ekonometrika (Edisi Kelima ed). Jakarta: Salemba Empat. Haniffa, Ros. 2002. Social Reporting Disclosure An Islamic Perspective. Indonesia Management \& Accounting Research 1 (2). pp. 128-146

Listiana, Bella Chynthia. 2015. Analisis Pengaruh Islamic Social Reporting Terhadap Kinerja Perusahaan (Studi Empiris Pada Bank Umum Syariah Di Indonesia). Skripsi tidak diterbitkan. Universitas Indonesia

Putra, Rizky Akbar. 2014. Pengaruh Profitabilitas, Struktur Modal, dan Likuiditas Terhadap Nilai Perusahaan. E-jurnal Fakultas Ekonomi dan Bisnis Universitas Brawijaya. Hal. 1-18.

Sudana, I Made. 2011. Manajemen Keuangan Perusahaan Teori Dan Praktek. Jakarta: Erlangga

Sujoko dan U. Soebiantoro. 2007. Pengaruh Struktur Kepemilikan Saham, Leverage, Faktor Intern dan Faktor Ekstern terhadap Nilai Perusahaan. Jurnal Manajemen dan Kewirusahaan, Vol 9, 47

Ulupui, I. G. K. 2007. Analisis Pengaruh Rasio Likuiditas, Leverage, Aktivitas dan Profitabilitas terhadap Return Saham. Jurnal Ilmiah Akuntansi dan Bisnis. Vol. 2, No. 1, p. 1-20. 